\title{
81. GEOTHERMAL MEASUREMENTS: THERMAL EVOLUTION OF THE JAPAN SEA BASINS AND SEDIMENTS ${ }^{1}$
}

\author{
Marcus G. Langseth ${ }^{2}$ and Kensaku Tamaki ${ }^{3}$
}

\begin{abstract}
Downhole temperature and thermal conductivity measurements in core samples recovered during Legs 127 and 128 in the Japan Sea resulted in five accurate determinations of heat flow through the seafloor and accurate estimates of temperature vs. depth over the drilled sections. The heat flows measured at these sites are in excellent agreement with nearby seafloor measurements. Drilling sampled basaltic rocks that form the acoustic basement in the Yamato and Japan basins and provided biostratigraphic and isotopic estimates of the age of these basins. The preliminary age estimates are compared with predicted heat flow values for two different thermal models of the lithosphere. A heat flow determination from the crest of the Okushiri Ridge yielded an anomalously high heat flow of $156 \mathrm{~mW} / \mathrm{m}^{2}$. This excessive heat flow value may have resulted from frictional heating on an active reverse fault that bounds the eastern side of the Ridge. Accurate estimates of sedimentation rates and temperatures in the sedimentary section combined with models of basin formation provide an opportunity to test thermochemical models of silica diagenesis. The current location of the opal-A/opal CT transition in the sedimentary section is determined primarily by the thermal history of the layer in which the transition is now found. Comparison of the ages and temperatures of the layer where the opal-A/opal-CT is found today is compatible with an activation energy of 14 to $17 \mathrm{kcal} / \mathrm{mole}$.
\end{abstract}

\section{INTRODUCTION}

The level and distribution of heat flow in the Japan Sea has been well determined by standard seafloor probe techniques (Yasui and Watanabe, 1965; Yasui et al., 1968; Yamano et al., 1987; Tamaki, 1986). Average heat loss is about $100 \mathrm{~mW} / \mathrm{m}^{2}$, which is appropriate for oceanic basins underlain by lower Miocene lithosphere that is cooling by conduction. The variation of heat flow within the Japan Sea is relatively small (Fig. 1). The most notable trends are (1) lower values of heat flow over the Yamato Rise, (2) a trend toward higher heat flow from west to east in the Japan basin, and (3) the mean heat flow values in the Japan and Yamato basins are equal at the $95 \%$ confidence level, even though the crustal structures of the two basins are dissimilar (Ludwig et al., 1975).

The six sites drilled during Ocean Drilling Program (ODP) Legs 127 and 128 in the Japan Sea provided an opportunity for measuring the temperature gradient in the upper 300 m of the sediment accurately as well as to measure thermal conductivity over the entire drilled section. The contact between sediments and igneous rocks was penetrated at three sites and provided direct indications of the age of basement. These improved age estimates and accurate heat-flow measurements provide stronger constraints on the tectonic development of the Yamato Basin and the eastern Japan Basin.

Holes at all six of the drill sites penetrated well-developed fronts of silica diagenesis. The sediments are highly silicious and, in pelagic sections, the location of the diagenetic fronts is controlled by the thermal history of the sedimentary section. A thermochemical model of the upward advance of opal-A/opal-CT transition (based on the thermal history of the Japan Sea basins and the sedimentation rate at each site) is presented that satisfactorily explains the current location of the opal-A/opal-CT boundary at five of the six sites.

\footnotetext{
'Tamaki, K., Suyehiro, K., Allan, J., McWilliams, M., et al., 1992. Proc. ODP, Sci. Results, 127/128, Pt. 2: College Station, TX (Ocean Drilling Program).

${ }^{2}$ Lamont-Doherty Geological Observatory of Columbia University, Palisades, NY 10964, U.S.A.

${ }^{3}$ Ocean Research Institute, University of Tokyo, Tokyo, Japan.
}

\section{METHODS}

\section{Temperature and Conductivity Measurements}

Downhole temperatures were measured using the Barnes/Uyeda water sampler and temperature probe (WSTP) (Yokota et al., 1979). This instrument records temperatures that are measured by a thermistor in the tip of a 1-m-long probe. The probe is deployed downhole and driven into the undisturbed sediment ahead of the drill bit. Figure 2 shows a typical temperature record made while the probe was held in the sediment for a period of 15 to $20 \mathrm{~min}$.

Thermal conductivities in unconsolidated sediments were measured by the heated needle probe technique (Von Herzen and Maxwell, 1959). Under ideal experimental conditions, the absolute accuracy is $\pm 3 \%$. Usually one or two measurements were performed per $1.5 \mathrm{~m}$ of core section. The most reliable measurements were those taken in cores recovered with the advanced hydraulic piston corer (APC). Sediments in APC cores suffer little mechanical disturbance; however, coring with the APC was restricted to the upper $150 \mathrm{~m}$ of unconsolidated diatomaceous ooze. At greater depths, where the sediment is semiconsolidated, the extended core barrel (XCB) was used. The XCB commonly produces many fine fractures in the sediment. As a consequence, measurements of thermal conductivity in XCB core samples are probably biased toward lower values and are less reliable than measurements in APC cores.

The thermal conductivities of consolidated sediments deep in the section and igneous rocks were measured using the half-space needle probe method. This technique is similar to the standard heated needle method, except that the probe is permanently bonded in a shallow groove in the surface of a slab of low thermal conductivity material. Samples are prepared for this type of measurement by grinding a smooth flat surface on a split section of core. The prepared sample is placed on the slab so that the probe is sandwiched between the flat face of the sample and the low conductivity slab. The experiments are performed in a constant temperature seawater bath. This is a calibrated technique and, generally, the accuracy of measurement is lower than that using the standard needle probe method.

Shipboard measurements of thermal conductivity, $K_{\text {lab, }}$, were corrected to in-situ conditions, $K_{\text {in-situ }}$, using the relationships reported by Ratcliffe (1960), 


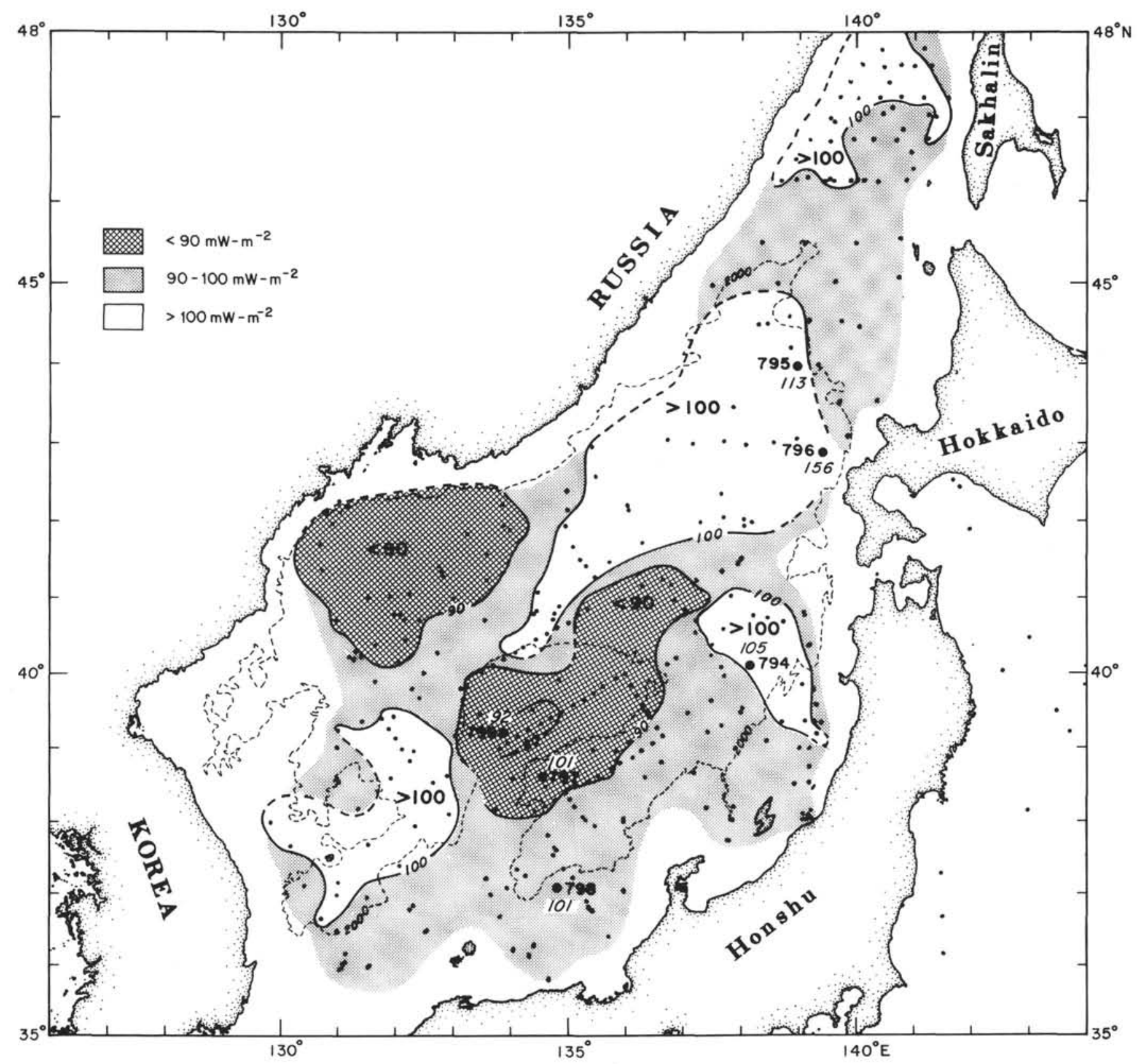

Figure 1. Distribution of heat flow in the Japan Sea. Small dots show the locations of seafloor probe measurements. The Leg 127 and 128 drill sites are shown as larger dots with the values of heat flow in italics. Broad areas are defined where the heat flow is predominantly less than $90 \mathrm{~mW} / \mathrm{m}^{2}$ and where the heat flow is greater than $100 \mathrm{~mW} / \mathrm{m}^{2}$; elsewhere, the heat flow lies between 90 and $100 \mathrm{~mW} / \mathrm{m}^{2}$.

$$
\begin{aligned}
K_{\text {in-situ }}= & K_{l a b} \times\left[1-0.0025 \cdot\left(T_{l a b}-T_{w}-z \cdot G\right)\right] \\
& \times\left[1+5.47 \times 10^{-6} \cdot\left(D_{w}+z\right)\right]
\end{aligned}
$$

where $\mathrm{T}_{\mathrm{lab}}$ is the laboratory temperature, $z$ is the depth below the seafloor in meters, $\mathrm{G}$ is the thermal gradient in the sediments, $T_{\mathrm{w}}$ is the bottom water temperature, and $D_{\mathrm{w}}$ is the water depth. Figure 3 shows profiles of corrected thermal conductivity and porosity measured in sediment cores at Site 797. These profiles are typical for pelagic sedimentary sections drilled in the Japan Sea. Thermal conductivity and porosity are relatively uniform from the seafloor to the opalA/opal-CT transition. Below this boundary, conductivity increases with depth as the sediments become more consolidated. The porosity profile shows an abrupt decrease of about $20 \%$ at this boundary.

\section{Gradient and Heat Flow estimates}

Reliable temperature measurements are used to estimate the gradient at each site by a linear least-squares fit of temperature vs. depth (Fig. 4). Temperature data from about $30 \%$ of the runs were discarded because of the faulty operation of the instrument or drilling disturbances. Appendix A contains a further discussion of sources of experimental error associated with use of the WSTP measurements. Heat flow is determined by plotting temperature vs. thermal resistance of the sedimentary section between the seafloor and the depth of the temperature measurements. The thermal resistance is calculated from the profiles of thermal conductivity using the following formula:

$$
R_{0 \rightarrow z_{N}}=z_{1} \cdot \rho_{1}+\sum_{i=1}^{N-1}\left(z_{i+1}-z_{i}\right) \cdot \frac{\left(\rho_{i+1}+\rho_{i}\right)}{2},
$$


Site 794 Run \#4 (depth 111 mbsf)
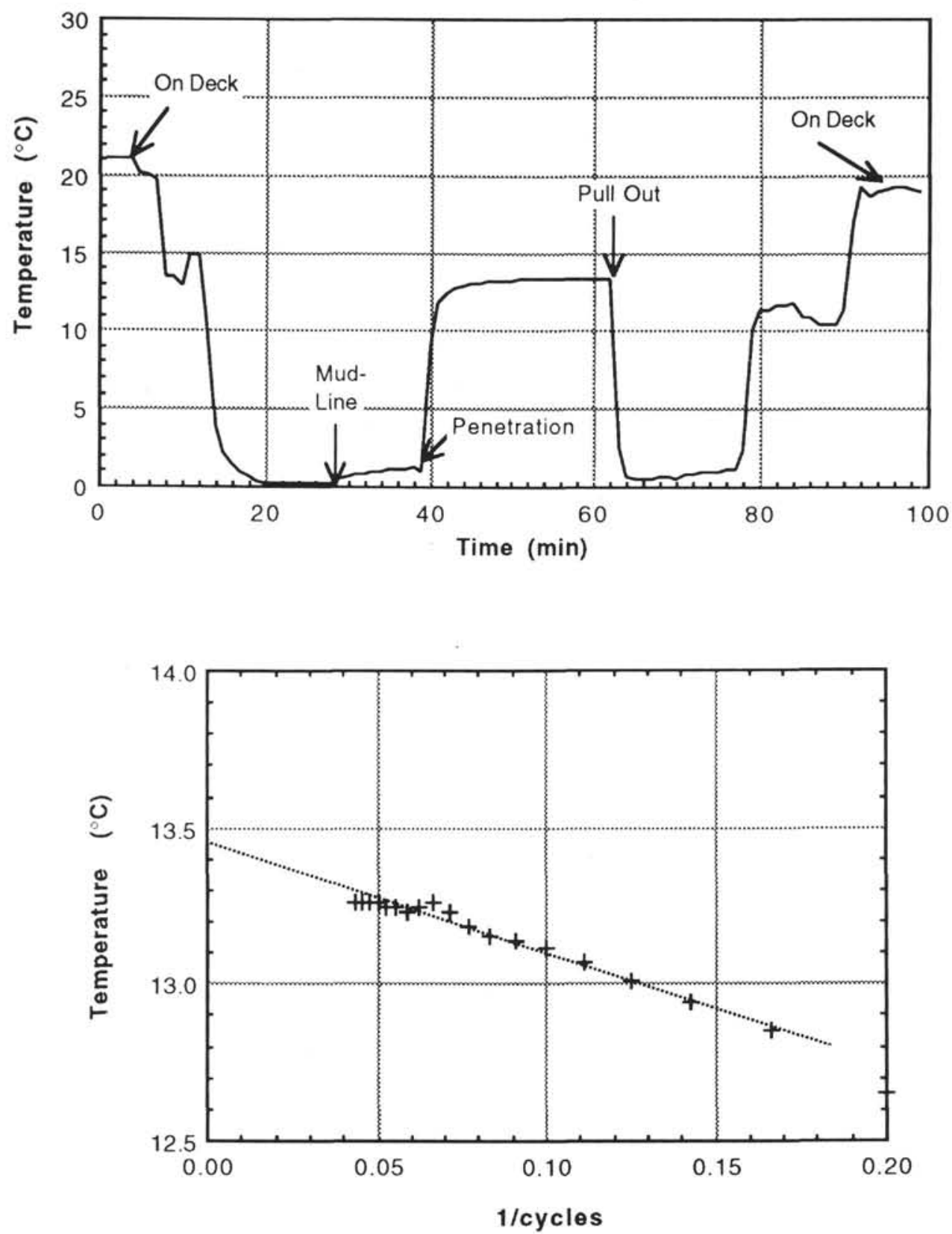

Figure 2. Top: Typical temperature recording by the Barnes/Uyeda WSTP tool shows the temperature history from turn-on aboard the ship until turn-off after the probe has been retrieved. Bottom: A plot of temperature vs. the reciprocal of time after penetration. The equilibrium temperature has been estimated by extrapolation to the zero intercept.

where $\mathrm{r}_{\mathrm{i}}$ is the $i$ th value of thermal resistivity (the reciprocal of thermal conductivity), $z_{\mathrm{i}}$ is the depth in mbsf of the $i$ th measurement, and $R_{0 \rightarrow z_{N}}$ is the thermal resistance of the sedimentary section between the seafloor and the depth, $z_{\mathrm{N}}$. The index, $i$, increases downward in the sedimentary section. For conductive heat flow in the vertical direction, temperature, $T(z)$ is related to the heat flow and thermal resistance by

$$
T(z)=T_{w}+q \cdot R_{0 \rightarrow z_{N}}
$$

where $\mathrm{q}$ is the amplitude of the heat-flow vector. Values of $q$ given in Table 1 are determined by the linear regression of $T$ vs. $R$ (Fig. 5).

All of the reliable downhole temperature measurements were performed with the WSTP at depths shallower than the opal-A/opalCT boundary; however, conductivities were measured for samples from the entire drilled section, which allowed us to use the heat-flow values and Equation 3 to extrapolate temperature profiles to the bottom of the hole (Fig. 6). 
Porosity (\%)

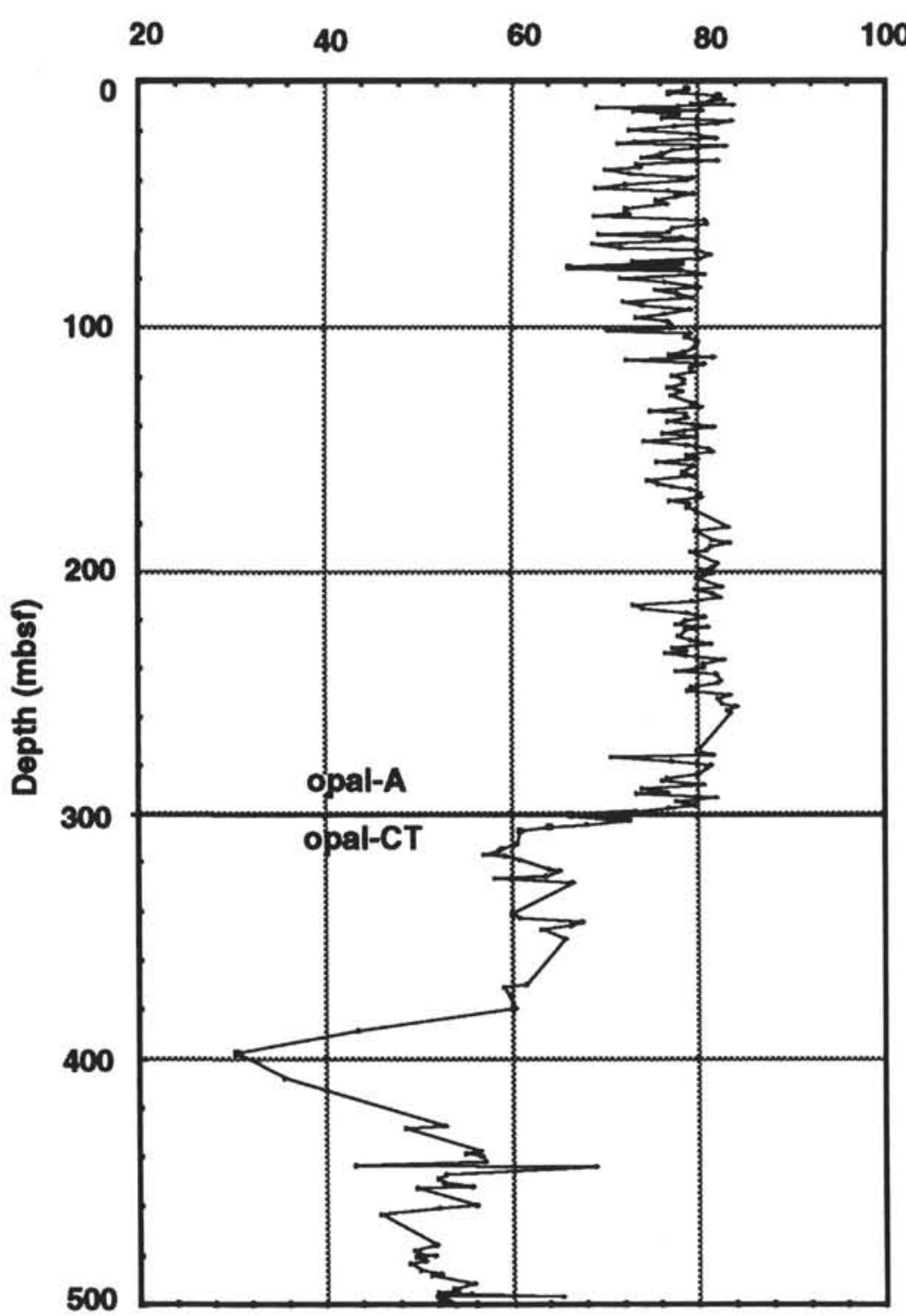

Conductivity $\left(\mathrm{W} / \mathrm{m}-{ }^{\circ} \mathrm{C}\right)$

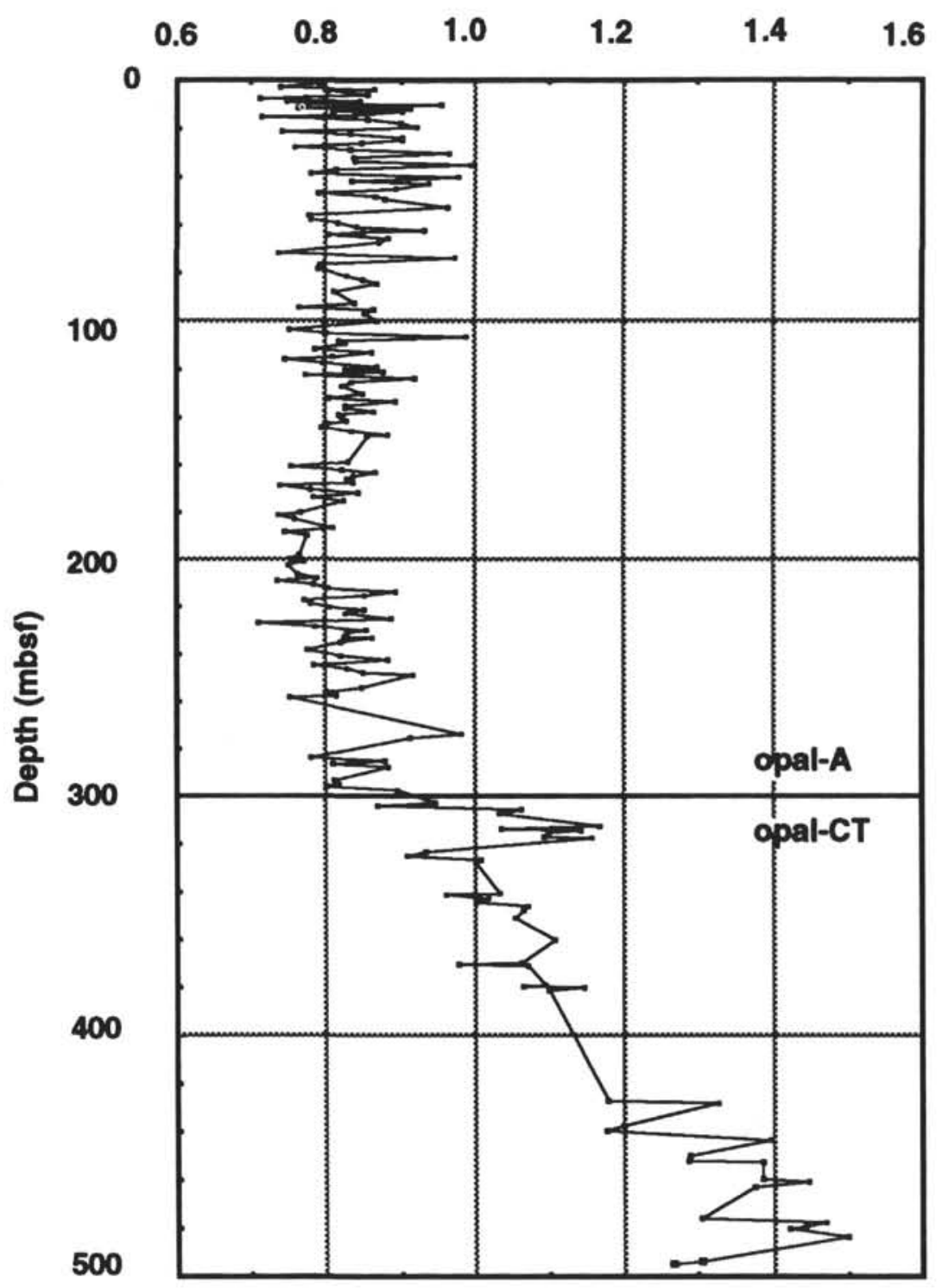

Figure 3. Thermal conductivity measurements corrected to in-situ pressure and temperature and porosity measured in core samples vs. depth at Site 797. Only measurements in the sedimentary section are shown. 


\section{RESULTS}

In Table 1 and Figures 4 through 6, we present our main geothermal results. In Table 2, we present additional seafloor probe measurements performed during Lamont-Doherty Geological Observatory (LDGO) cruises in the Japan Sea that have not been published previously. These data contribute to defining the distribution of heat flow of the Japan Basin, especially the western part of the basin, which has been sampled sparsely. The downhole temperature measurements at each site describe a linear increase with depth and with thermal resistance, indicating that the thermal gradients and heat flow are uniform with depth (Figs. 4 and 5). These results rule out significant heat production in the sedimentary section, transient heat flow, or a significant lateral flow of heat in the measured section. The heat flow calculated at each of these sites is in excellent agreement with nearby seafloor probe measurements and fits the general trends of heat flow within the Japan Sea. This agreement provides a convincing demonstration that, on the whole, the extensive seafloor probe results truly represent the distribution of heat flow from the lithosphere that underlies the Japan Sea. In some areas of the Japan Sea, the sedimentation rate is high enough

Table 1. Geothermal measurements during Legs 127 and 128: Japan Sea.

\begin{tabular}{|c|c|c|c|c|c|c|c|c|c|c|c|}
\hline \multirow[b]{2}{*}{ Hole } & \multicolumn{2}{|c|}{ Position } & \multirow[b]{2}{*}{$\begin{array}{l}\text { Water } \\
\text { depth } \\
\text { (m) }\end{array}$} & \multirow[b]{2}{*}{ NA } & \multirow[b]{2}{*}{ NR } & \multicolumn{2}{|c|}{ Temperature gradient } & \multirow[b]{2}{*}{ NK } & \multicolumn{2}{|c|}{ Conductivity } & \multirow[b]{2}{*}{$\begin{array}{l}\text { Heat flow } \\
\left(\mathrm{mW} / \mathrm{m}^{2}\right)\end{array}$} \\
\hline & $\begin{array}{c}\text { Latitude } \\
\left({ }^{\circ} \mathrm{N}\right)\end{array}$ & $\begin{array}{c}\text { Longitude } \\
\left({ }^{\circ} \mathrm{E}\right)\end{array}$ & & & & $\begin{array}{l}\text { Maximum } \\
\text { depth }(m)\end{array}$ & $\begin{array}{c}\text { Gradient } \\
(\mathrm{K} / \mathrm{m})\end{array}$ & & $\begin{array}{l}\text { Average } \\
(\mathrm{W} / \mathrm{m} \cdot \mathrm{K})\end{array}$ & $\begin{array}{l}\text { Std. Dev. } \\
(\mathrm{W} / \mathrm{m} \cdot \mathrm{K})\end{array}$ & \\
\hline $794 \mathrm{~A}$ & 40.190 & 138.231 & 2811 & 13 & 8 & 112.3 & 0.118 & 76 & 0.886 & 0.081 & 105 \\
\hline $795 \mathrm{~A}$ & 43.987 & 138.967 & 3300 & 6 & 4 & 163.4 & 0.132 & 99 & 0.854 & 0.062 & 113 \\
\hline${ }^{2} 796 \mathrm{~A}$ & 42.849 & 139.411 & 2571 & 4 & 1 & 23.2 & & & & & \\
\hline $796 \mathrm{~B}$ & 42.849 & 139.414 & 2622 & 3 & 2 & 79.8 & 0.178 & 40 & 0.879 & 0.076 & 156 \\
\hline $797 \mathrm{~B}$ & 38.616 & 134.536 & 2862 & 7 & 5 & 185.5 & 0.121 & 113 & 0.838 & 0.068 & 101 \\
\hline $798 \mathrm{~A}$ & 37.038 & 134.800 & 903 & 6 & 5 & 133.8 & 0.116 & 53 & 0.874 & 0.096 & 101 \\
\hline $798 B$ & 37.038 & 134.799 & 900 & 5 & 5 & 111.4 & 0.117 & 45 & 0.875 & 0.089 & 102 \\
\hline $799 \mathrm{~A}$ & 39.22 & 133.867 & 2073 & 8 & 7 & 175.5 & 0.095 & 76 & 0.965 & 0.132 & 91.7 \\
\hline
\end{tabular}

$\mathrm{NA}=$ number of downhole temperature measurements attempted; $\mathrm{NR}=$ number of reliable downhole temperature measurements; $\mathrm{NK}=$ number of conductivity measurements between the seafloor and the deepest downhole temperature measurement. Maximum depth is the deepest temperature point used to calculate gradients.

${ }^{a}$ Results from Holes 796A and 796B are combined to calculate gradient.

Table 2. LDGO geothermal data from the Japan Sea.

\begin{tabular}{|c|c|c|c|c|c|c|c|c|}
\hline $\begin{array}{l}\text { Station } \\
\text { number }\end{array}$ & $\begin{array}{c}\text { Latitude } \\
\text { (N) }\end{array}$ & $\begin{array}{l}\text { Longitude } \\
\text { (E) }\end{array}$ & $\begin{array}{l}\text { Depth } \\
\text { (m) }\end{array}$ & NP & NK & $\begin{array}{c}\text { Grad. } \\
(\mathrm{mK} / \mathrm{m})\end{array}$ & $\begin{array}{c}\text { Cond. } \\
(\mathrm{W} / \mathrm{m} \cdot \mathrm{K})\end{array}$ & $\begin{array}{l}\text { Heat flow } \\
\left(\mathrm{mW} / \mathrm{m}^{2}\right)\end{array}$ \\
\hline RC $12-195$ & $37^{\circ} 15^{\prime}$ & $135^{\circ} 43^{\prime}$ & 1622 & & 3 & $* * * *$ & 0.72 & $* * * *$ \\
\hline RC $12-196$ & $39^{\circ} 55^{\prime}$ & $132^{\circ} 40^{\prime}$ & 3027 & & 13 & $* * * *$ & 0.787 & $* * * *$ \\
\hline RC $12-197$ & $40^{\circ} .50^{\prime}$ & $134^{\circ} 26^{\prime}$ & 3532 & 3 & 9 & 71 & 0.766 & 54.4 \\
\hline RC $12-199$ & $38^{\circ} 55^{\prime}$ & $136^{\circ} 30^{\prime}$ & 2650 & & 11 & ***** & 0.8 & $* * * *$ \\
\hline V $28-144$ & $36^{\circ} 58^{\prime}$ & $131^{\circ} 29^{\prime}$ & 2109 & 4 & 4 & 125 & 0.724 & 90.9 \\
\hline V $28-145$ & $36^{\circ} 17^{\prime}$ & $134^{\circ} 34^{\prime}$ & 1218 & 4 & 6 & 116 & 0.729 & 84.3 \\
\hline V $28-146$ & $37^{\circ} 5^{\prime}$ & $133^{\circ} 56^{\prime}$ & 1880 & 4 & 5 & 125 & 0.712 & 89.1 \\
\hline V $28-147$ & $38^{\circ} 38^{\prime}$ & $132^{\circ} 53^{\prime}$ & 2831 & 4 & 6 & 132 & 0.754 & 99.3 \\
\hline V $28-148$ & $38^{\circ} 37^{\prime}$ & $136^{\circ} 20^{\prime}$ & 2692 & 4 & & 121 & 0.754 & 91.0 \\
\hline V $28-149$ & $38^{\circ} 2^{\prime}$ & $137^{\circ} 50^{\prime}$ & 1796 & 3 & 7 & 89 & 0.896 & 79.9 \\
\hline V $28-150$ & $39^{\circ} 29^{\prime}$ & $137^{\circ} 4^{\prime}$ & 2534 & 3 & 9 & 119 & 0.741 & 88.5 \\
\hline V $28-151$ & $40^{\circ} 45^{\prime}$ & $138^{\circ} 27^{\prime}$ & 3382 & 4 & 8 & 121 & 0.812 & 98.2 \\
\hline V $28-152$ & $42^{\circ} 12^{\prime}$ & $136^{\circ} 2^{\prime}$ & 3610 & 4 & 8 & 115 & 0.783 & 90.0 \\
\hline V $28-153$ & $41^{\circ} 29^{\prime}$ & $135^{\circ} 43^{\prime}$ & 3533 & 3 & 4 & 112 & 0.808 & 90.5 \\
\hline V $28-154$ & $39^{\circ} 38^{\prime}$ & $137^{\circ} 28^{\prime}$ & 2677 & 3 & 5 & 120 & 0.896 & 108.0 \\
\hline V $28-156$ & $40^{\circ} 44^{\prime}$ & $134^{\circ} 44^{\prime}$ & 3027 & 4 & 6 & 124 & 0.796 & 99.0 \\
\hline V $28-157$ & $37^{\circ} 57^{\prime}$ & $135^{\circ} 28^{\prime}$ & 2922 & 3 & 9 & 133 & 0.779 & 104.0 \\
\hline V $28-158$ & $37^{\circ} 33^{\prime}$ & $134^{\circ} 44^{\prime}$ & 2902 & 2 & 8 & 126 & 0.754 & 95.3 \\
\hline V $28-160$ & $41^{\circ} 15^{\prime}$ & $137^{\circ} 13^{\prime}$ & 3535 & 4 & 6 & 128 & 0.762 & 97.5 \\
\hline V $28-161$ & $43^{\circ} 25^{\prime}$ & $136^{\circ} 21^{\prime}$ & 3588 & 3 & 13 & 146 & 0.724 & 105.0 \\
\hline V $28-162$ & $42^{\circ} 36^{\prime}$ & $138^{\circ} 9^{\prime}$ & 3652 & 4 & 8 & 126 & 0.804 & 102.0 \\
\hline V $32-047$ & $41^{\circ} 27^{\prime}$ & $137^{\circ} 59^{\prime}$ & 3674 & 3 & 10 & 123 & 0.727 & 89.4 \\
\hline V $32-048$ & $41^{\circ} 10^{\prime}$ & $136^{\circ} 17^{\prime}$ & 3429 & 3 & 7 & 115 & 0.778 & 89.5 \\
\hline V $32-049$ & $40^{\circ} 54^{\prime}$ & $134^{\circ} 57^{\prime}$ & 3485 & 5 & 18 & 119 & 0.741 & 88.1 \\
\hline V $32-050$ & $40^{\circ} 43^{\prime}$ & $133^{\circ} 33^{\prime}$ & 3470 & 4 & 18 & 129 & 0.732 & 94.4 \\
\hline V $32-051$ & $40^{\circ} 22^{\prime}$ & $131^{\circ} 41^{\prime}$ & 3308 & 3 & 7 & 127 & 0.755 & 95.9 \\
\hline V $32-052$ & $41^{\circ} 21^{\prime}$ & $130^{\circ} 44^{\prime}$ & 3057 & 4 & 0 & 119 & $* * * *$ & 90.0 \\
\hline V $32-054$ & $41^{\circ} 17^{\prime}$ & $132^{\circ} 49^{\prime}$ & 3444 & 2 & 5 & 127 & 0.733 & 93.1 \\
\hline V 32-055 & $41^{\circ} 49^{\prime}$ & $133^{\circ} 15^{\prime}$ & 3483 & 5 & 11 & 110 & 0.781 & 85.9 \\
\hline V $32-056$ & $44^{\circ} 18^{\prime}$ & $138^{\circ} 53^{\prime}$ & 3399 & 5 & 12 & 126 & 0.718 & 90.5 \\
\hline
\end{tabular}

$\mathrm{NP}=$ Number of working probes that penetrated the seafloor. NK $=$ Number of thermal conductivity measurements. 


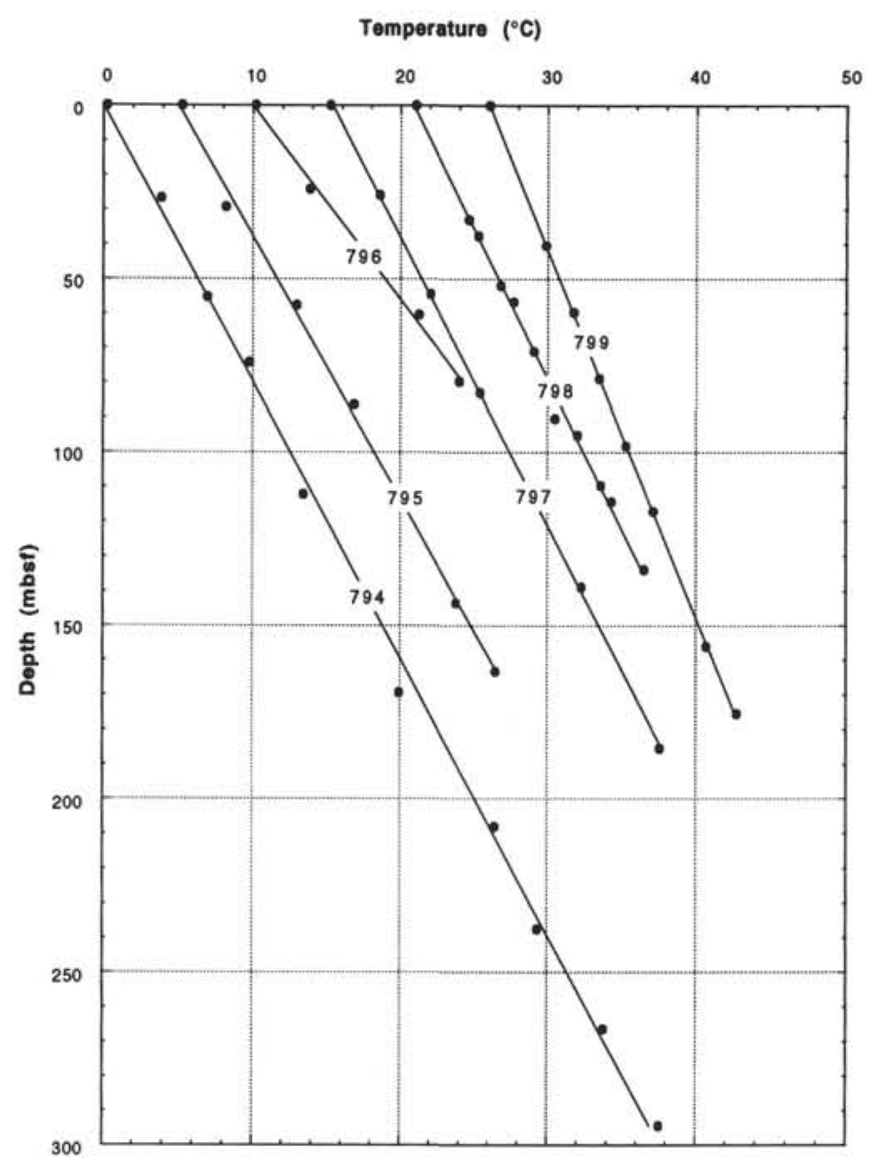

Figure 4. Downhole temperature measurements vs. depth at Leg 127 and 128 sites. To prevent overlap, temperatures have been progressively displaced $5^{\circ}$ to the right with increasing site number.

to cause a slight reduction in heat flux from the crust. The magnitude of this effect can be estimated from the sedimentation rate and the porosity curves, but a detailed analysis is beyond the scope of this study. The only site during Legs 127 and 128 where this effect might be significant is Site 798 , where the sedimentation rate is about $100 \mathrm{~m} / \mathrm{m} . \mathrm{y}$. The estimated decrease in heat flow from rapid sedimentation should be about $10 \%$.

Two sites were drilled in the Yamato Basin: Sites 794 and 797. The heat flow value at Site $794\left(105 \mathrm{~mW} / \mathrm{m}^{2}\right)$ is slightly higher than that at Site $797\left(101 \mathrm{~mW} / \mathrm{m}^{2}\right)$, indicating that the lithosphere at Site 794 may be younger. The average value of heat flow at these two sites of about $103 \mathrm{~mW} / \mathrm{m}^{2}$ probably better represents the heat loss from the Yamato Basin than the mean of earlier seafloor probe measurements $\left(98 \mathrm{~mW} / \mathrm{m}^{2}\right)$. Many of the seafloor measurements were made in the vicinity of the Yamato Seamount Chain, which runs along the axis of the basin (Tamaki, 1988). Basement exposures on these seamounts may promote convective heat loss from the central part of the basin and may bias measurements of conductive heat flow toward lower values.

At Site 795, in the northeastern corner of the Japan Basin, the measured heat flow is $113 \mathrm{~mW} / \mathrm{m}^{2}$. This relatively high value is within a broad area of generally higher heat flow $\left(100 \mathrm{~mW} / \mathrm{m}^{2}\right)$ in the eastern part of the Japan Basin (Fig. 1), and it is significantly higher than the heat flow in the Yamato Basin or the western Japan Basin. This difference might indicate a younger age for this part of the Japan Basin than for the Yamato Basin or the western Japan Basin. The result is in accord with the age of acoustic basement determined from extrapolating biostratigraphically determined sedimentation rates to acoustic

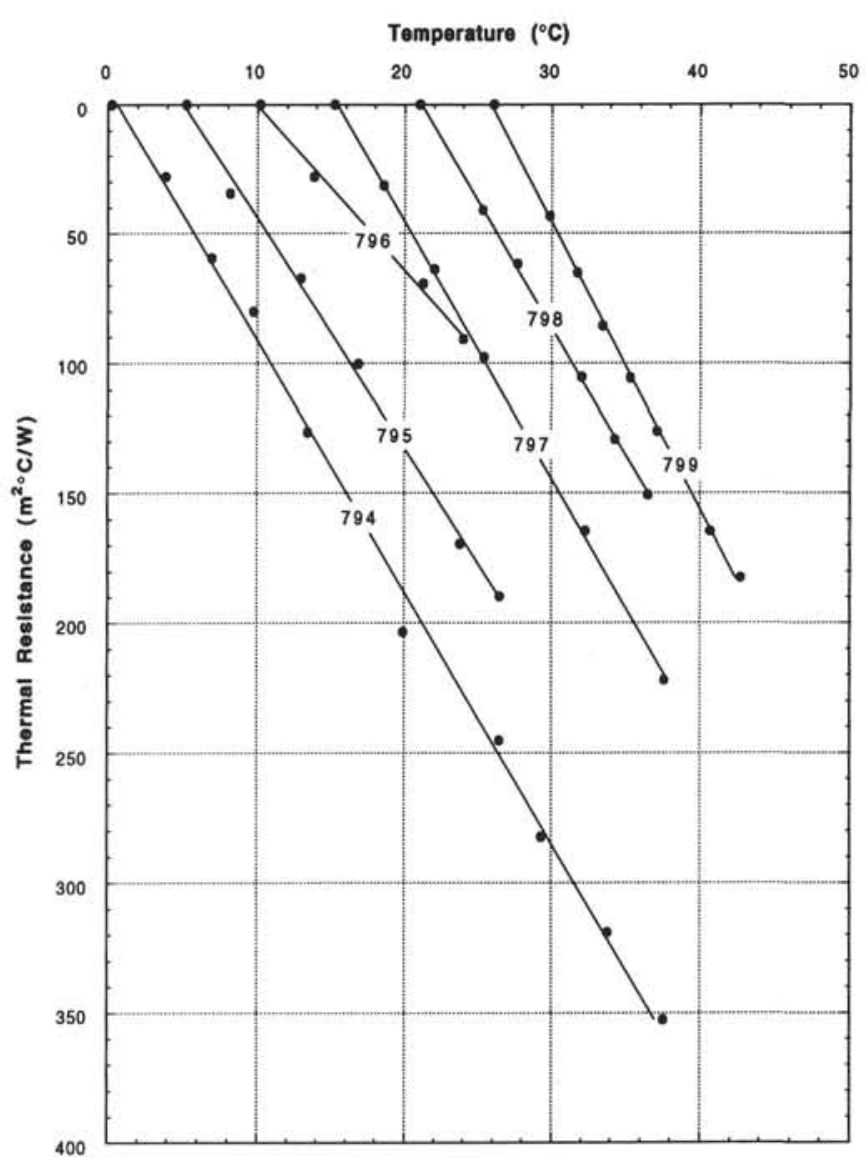

Figure 5. Temperature vs. thermal resistance of sediments between the seafloor and the depth of measurement for Leg 127 and 128 sites. The slope, $\frac{d T}{d R}$, is equal to the heat flow. Temperatures have been displaced in the same manner as Figure 4 for clarity.

basement (Table 3). Seismic-refraction studies show that the structure below the Japan Basin is oceanic in character and has a crustal thickness of about $12 \mathrm{~km}$ (Ludwig et al., 1975), whereas the crust below the Yamato Basin is significantly thicker. This suggests that the higher heat flow at Site 795 may be related to the mode of formation of the lithosphere, rather than the age. These possibilities are examined in the next section in the context of a lithospheric stretching model of basin formation.

The heat flow value observed at Site 798 on top of the Oki Ridge is the same as that at Site 797 and is not significantly different from the average heat flow in Yamato Basin. Nearby seafloor probe measurements support this observation. The Oki Ridge is a spurlike ridge having a rifted crest that protrudes northeastward into the Yamato Basin, separating it from the narrow Oki Trough to the southeast. It appears to be a remanent fragment of crust of continental provenance. The equality of heat flow on this ridge with that in the adjacent basin suggests that the mantle beneath the ridge was reheated during opening of the Yamato Basin. Radiogenic heat in the continental rocks underlying the Oki Ridge may make a $15 \%$ to $25 \%$ contribution to the surface heat flow (Pollack and Chapman, 1977). If so, then the mantle below the Oki Ridge may have been heated to a lesser extent and the equality with values in adjacent basins is coincidental.

The Yamato Rise is thought to be a large fragment of crust having continental and arc affinities. Seafloor probe measurements have shown that the heat flow over this broad feature is somewhat lower than in the adjacent basins (Fig. 1). The measurement performed during Leg 128 at Site $799\left(92 \mathrm{~mW} / \mathrm{m}^{2}\right)$ is in line with this observation. 


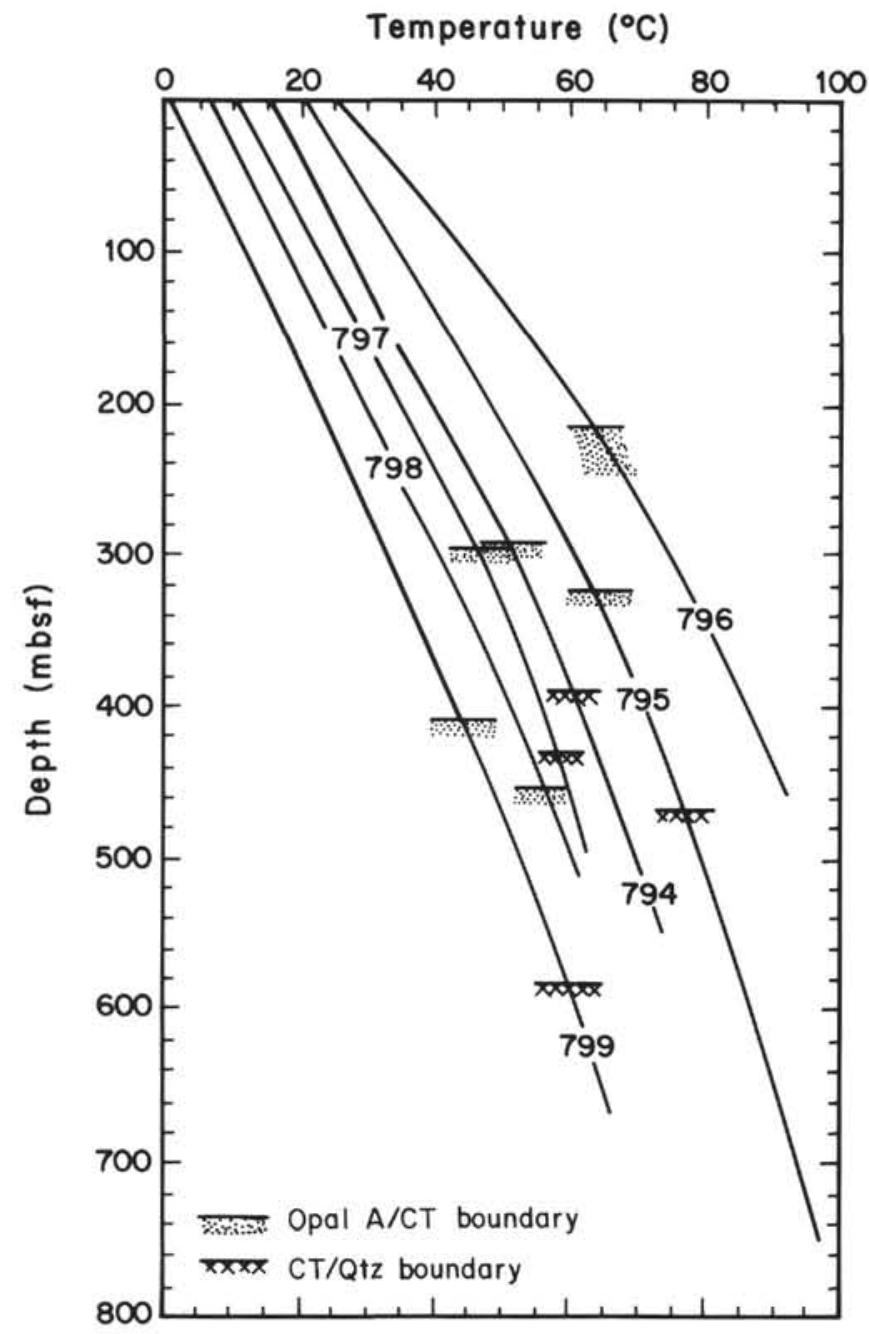

Figure 6. Estimated temperature vs. depth profiles through the entire drilled section calculated from heat flow values and the conductivity profiles using Equation 3. The locations of the opal-A/opal-CT and CT/Qtz transitions are shown. Except for Site 799, temperatures have been displaced to the right to prevent overlap of the profiles.

The present-day lower heat flow over this rise is probably a consequence of lower initial mantle temperatures at the time of rifting, because the lithosphere below the rise was not thinned appreciably during opening of the Japan Sea basins. Again, crustal radiogenic heat may contribute to the heat flux from the Yamato Rise.

Site 799 is located in the floor of a deep, sediment-filled rift that cuts northeastward across the Yamato Rise. The fact that the present level of heat flow in this feature is about the same as the average over the Yamato Rise suggests that formation of this graben occurred during the very early stages of the opening of the Japan Sea and that little if any magmatic activity took place in this graben subsequent to its formation.

The heat flow at Site 796 is anomalous. The heat flow (156 $\mathrm{mW} / \mathrm{m}^{2}$ ) is significantly higher than at the other five sites and nearby seafloor probe measurements. The measurement is located near the crest of the Okushiri Ridge and is among the highest observed in the Japan Sea. Strong seismic activity and deformed sediments in the vicinity of the ridge suggest it is being obducted by reverse faulting. The current vertical displacement is about $1 \mathrm{~km}$. Tamaki (1988) proposed that the Okushiri Ridge lay along a newly formed zone of plate convergence and that the reverse faulting may be the start of a new subduction zone. The lithostratigraphy and biostratigraphy at
Table 3. Age of acoustic basement and observed heat flow for three Leg 127/128 sites.

\begin{tabular}{lccc}
\hline Site & \multicolumn{2}{c}{ Basement age (Ma) } & \\
& Biostratigraphy & ${ }^{40} \mathrm{Ar}^{39} \mathrm{Ar}$ & $\begin{array}{l}\text { Heat flow } \\
\left(\mathrm{mW} / \mathrm{m}^{2}\right)\end{array}$ \\
\hline 794 & $15.5 \pm 0.7$ & $20-21$ & $105 \pm 5$ \\
795 & $14.0 \pm 1.0$ & $17-24$ & $113 \pm 3$ \\
797 & $19.0 \pm 1.0$ & $18-19$ & $101 \pm 3$ \\
\hline
\end{tabular}

Site 796 allowed us to date the start of uplift of the Okushiri Ridge as 1.8 Ma (Tamaki, Pisciotto, Allan, et al., 1990). A preliminary analysis, which will be reported elsewhere, suggests that the increased heat flow at the crest of the Okushiri Ridge may be the result of the combined effects of frictional heating along the thrust plane of the reverse fault and of focusing of the heat flow by the upward flux of pore water through the sediments above the faulted zone in basement.

\section{DISCUSSION}

\section{Heat Flow and the Age of the Japan Sea Basins}

Heat-flow measurements in the mid-1960s (Yasui and Watanabe, 1965; Yasui et al., 1967) and interpretation of backarc basins as a feature formed by rifting and seafloor spreading (Karig, 1971) imply an early Miocene age for the Japan Sea basins (Watanabe et al., 1977). During the past decade, studies of small basins in western Honshu (Ingle, 1975) and paleomagnetic studies by Otofuji and Matsuda (1983) and Otofuji et al. (1985) and further studies of heat flow and seismic stratigraphy (Tamaki, 1986) have further constrained the age estimates to a range of 12 to $25 \mathrm{Ma}$. These studies have also provided a kinematic picture of the opening of the basins by a clockwise rotation of southwestern Honshu and a counterclockwise rotation of northern Honshu away from the Siberian continental landmass (Kawai et al., 1971; Otofuji and Matsuda, 1983; Otofuji et al., 1985). However, the timing of these movements remains uncertain. Drilling during Legs 127 and 128 yielded the first direct determinations of the age of basement. These ages, combined with accurate heat-flow measurements at the same locations, provide important new constraints on the thermal and tectonic evolution of the Japan Sea basins.

The basement ages at Sites 794, 795, and 797 were estimated by the two following approaches:

1. The age of the uppermost contact between sediments and volcanic rocks was estimated by downward extrapolation of sedimentation rates established by biostratigraphic data (Tamaki, Pisciotto, Allen, et al., 1990).

2. ${ }^{40} \mathrm{Ar} /{ }^{39} \mathrm{Ar}$ ages of volcanic rock samples (Kaneoka et al., this volume).

The estimates based on the two different approaches are listed in Table 3. The agreement between the two methods of estimating age at Site 797 is good, but significant discrepancies occur between the basement ages estimates at Sites 794 and those at Site 795, where isotopic dating indicates significantly older ages than biostratigraphic estimates.

Both approaches to estimating basement age have significant uncertainties. The accuracy of estimates from sedimentation rates suffers from the very poor preservation of fossils below the opalA/opal-CT transition, that is, the lower half of the sedimentary section. With such sparse biostratigraphic control in the lower section, we cannot rule out the possibility of missing sections of sediment in the columns that were drilled. If true, then the age estimates based on biostratigraphy would have to be increased, and the agreement with the isotopic ages at Site 794 and Site 795 would be improved. On the other hand, isotopically determined basement ages may be corrupted by the pervasive alteration of the basaltic rocks drilled during 
Leg 127; in particular, the ${ }^{40} \mathrm{Ar} /{ }^{39} \mathrm{Ar}$ ages for rocks from Site 795 have large uncertainties (Kaneoka et al., in this volume).

Questions common to both types of basement age estimates in the Yamato Basin are relevant. For example, when were the flows and sills at the base of the sedimentary section emplaced relative to the formation of the lithosphere that underlies the basin? Are they contemporaneous with formation of the underlying crust, or are they the result of later magmatic activity?

The accuracy of the heat-flow measurements is comparable to that of the age estimates; however, heat-flow values provide only a rough indicator of the time that has elapsed since the last thermal event in a region. Uncertainties arise when estimating the time of formation of a basin or the emplacement of a magma body because these estimates are based on a thermal model of the event. Uncertainty in initial conditions, such as temperature distribution, will lead to sizable errors in the absolute age estimated on the basis of heat flow. However, heat-flow values can provide a powerful constraint if they are used as a comparative tool. For example, comparing the heat flow from one region with another can be a good guide to the relative age, or comparing the heat flow of a region with that predicted by a wellknown tectonic or thermal model of the lithosphere may provide insight into its formation and evolution. One such model is the empirical relation of Parsons and Sclater (1977), which fits the heat-flow variation and subsidence data of the North Pacific Ocean lithosphere. We will refer to this model as the Pacific Plate oceanic model or PPOM.

In the Yamato Basin, extrapolation of sedimentation rates yields an age of $15.5 \mathrm{Ma}$ at Site 794 and $19 \mathrm{Ma}$ at Site 797. This age difference is difficult to reconcile with the small difference in heat flow $\left(4 \mathrm{~mW} / \mathrm{m}^{2}\right)$, unless the mode of lithosphere formation (i.e., the initial thermal conditions) differed between Sites 794 and 797. Isotopic dating of igneous rocks sampled in the Yamato Basin yielded ages of 18 to $19 \mathrm{Ma}$ at Site 797 and 20 to $21 \mathrm{Ma}$ at Site 794. However, the younger isotopic dates for rocks were found at Site 797. This difference in age is opposite in sense to that suggested by the difference in heat flow as well as to that determined from biostratigraphy. Using the average heat flow at the two Yamato Basin sites (103 $\mathrm{mW} / \mathrm{m}^{2}$ ) and the empirical heat flow/age relation for PPOM results in an estimated age for the lithosphere of 20 to $21 \mathrm{Ma}$, which is in reasonable agreement with the estimates of basement age by the ${ }^{40} \mathrm{Ar} /{ }^{39} \mathrm{Ar}$ method, but significantly older than the age of basement at Site 794 based on extrapolation of the sedimentation history.

The only hole drilled to acoustic basement in the Japan Basin is Site 795. It is located in the far northeastern corner of the basin. Evidence is fairly convincing that the lithosphere below the Japan Basin is oceanic in character. The refraction results of Ludwig et al. (1975) showed that the seismic structure at two stations near Site 795 (sonobuoys 158 and 159) is oceanic. Hole 795B penetrated $78 \mathrm{~m}$ of basaltic rock, which is similar to oceanic basalts, without encountering interbedded sediments. Thus, it seems likely that the ages of igneous rocks drilled at this site represent the age of the crust and lithosphere below.

The biostratigraphic control on the sedimentation rate at Site 795 is the best of the three sites where basement was reached; however, the extrapolated age ( $14 \pm 1 \mathrm{Ma})$ may be an underestimate because the site is located on a basement high and a significant part of the section may be missing (Tamaki, Pisciotto, Allan, et al., 1990). The higher heat flow at Site $795\left(113 \mathrm{~mW} / \mathrm{m}^{2}\right)$ is consistent with a lithospheric age that is younger than that in the Yamato Basin. If we compare the heat flow with the PPOM, an estimated age for the lithosphere of about 17 Ma results. Further support for a relatively young age comes from the fact that the unloaded basement depth at Site $795(3780 \mathrm{~m})$ falls very close to the PPOM subsidence curve at $14 \mathrm{Ma}$. However, age estimates of backarc basin lithospheres (based on depth to basement) are risky because the depth of the seafloor at zero age is unconstrained and is known to vary greatly among other backarc basins (Watanabe et al., 1977). The age of basement rocks at Site 795, determined by the ${ }^{40} \mathrm{Ar} /{ }^{39} \mathrm{Ar}$ method, ranges from is 17 to $24 \mathrm{Ma}$ (Kaneoka et al., in this volume). The ages obtained are less reliable than those at Sites 794 or 797 . The biostratigraphic ages lie outside the range of isotopic ages; thus, the two methods of estimating age can only be reconciled if we assume a large section of sediment just above basement is missing.

\section{Comparison of Heat Flow and Estimated Basement Ages with a Lithospheric Stretching Model}

Generally, the heat flow in the Yamato Basin is low compared to the heat flow predicted by PPOM and the estimates of basement age at Sites 794 and 797. This suggests that the tectonic processes of basin formation may have brought less heat to the top of the lithosphere than is typical for mid-oceanic ridges. One such process was proposed by McKenzie (1978), who envisioned the formation of certain basins by stretching of the lithosphere. He proposed a simple mechanical and thermal model to simulate the process. The fundamental assumption in McKenzie's model is that the strain at the boundary where two lithospheric plates are moving apart is distributed over a wide zone. As a consequence, the crust and lithosphere are thinned by pure shear in this zone, and isostatic adjustment to thinning of the lithosphere brings high-temperature asthenospheric material closer to the surface, which increases the temperature gradients in the lithosphere. The evolution of surface heat flow and vertical temperature distribution predicted by the McKenzie model can be put in the form of a simple analytic expression, which is derived in Appendix B. The surface heat flow as a function of time and lithospheric thickness immediately after stretching, $D$, is given by

$$
q(0, t)=\frac{K_{B} \cdot T_{m}}{D} \cdot \operatorname{erf}[D / 2 \sqrt{\kappa t}] .
$$

When $\mathrm{D}=0$, then

$$
q(0, t)=\frac{K_{B} \cdot T_{m}}{\sqrt{\pi \kappa t}}
$$

Royden et al. (1979) suggested an alternative mechanism for basin formation by extension of the lithosphere. Their model envisioned a massive injection of mafic dikes into the continental crust in the stretching zone, which would raise the temperature of the upper lithosphere and crust and at the same time increase the density of the lithosphere so that the basin would subside rapidly in the early stages of rifting. The thermal evolution of the basin subsequent to stretching is similar to that predicted by the McKenzie model. The complex pattern of magnetic anomalies, the prevalence of volcanic structures in the Yamato Basin, and the considerable intrusive volcanism that accompanied opening of the Yamato Basin all suggest that the model of Royden et al. (1979) may be a more realistic geological history for this basin.

Figure 7 shows model heat flows as a function of age in a basin formed by stretching of the lithosphere for selected values of $D$ between 0 and $30 \mathrm{~km}$, predicted by Equations 4 and 5 . The points corresponding to basement age estimates and heat flows at Sites 794, 795, and 797 are shown in the same figure. The curve for $D=0$ in Figure 7 describes a cooling half space, which is a good approximation to the heat flow age relation of the PPOM.

The average level of heat flow in the Yamato Basin $\left(103 \mathrm{~mW} / \mathrm{m}^{2}\right)$ is compatible with preliminary age estimates, if we assume that the basin formed by stretching of the lithosphere. Comparison of heat flow with the model results suggests that a $15-$ to $25-\mathrm{km}$-thick lithosphere immediately after stretching would evolve to the present level of heat flow in 18 to $19 \mathrm{Ma}$. The thicker oceanic crust in the Yamato Basin (defined by seismic refraction profiles; Ludwig et al., 1975) favors formation of the basin by distributed extensional strain of the lithosphere.

Comparison of basement age estimates to the measured heat flow of $113 \mathrm{~mW} / \mathrm{m}^{2}$ at Site 795 in the Japan Basin leads to contradictory 


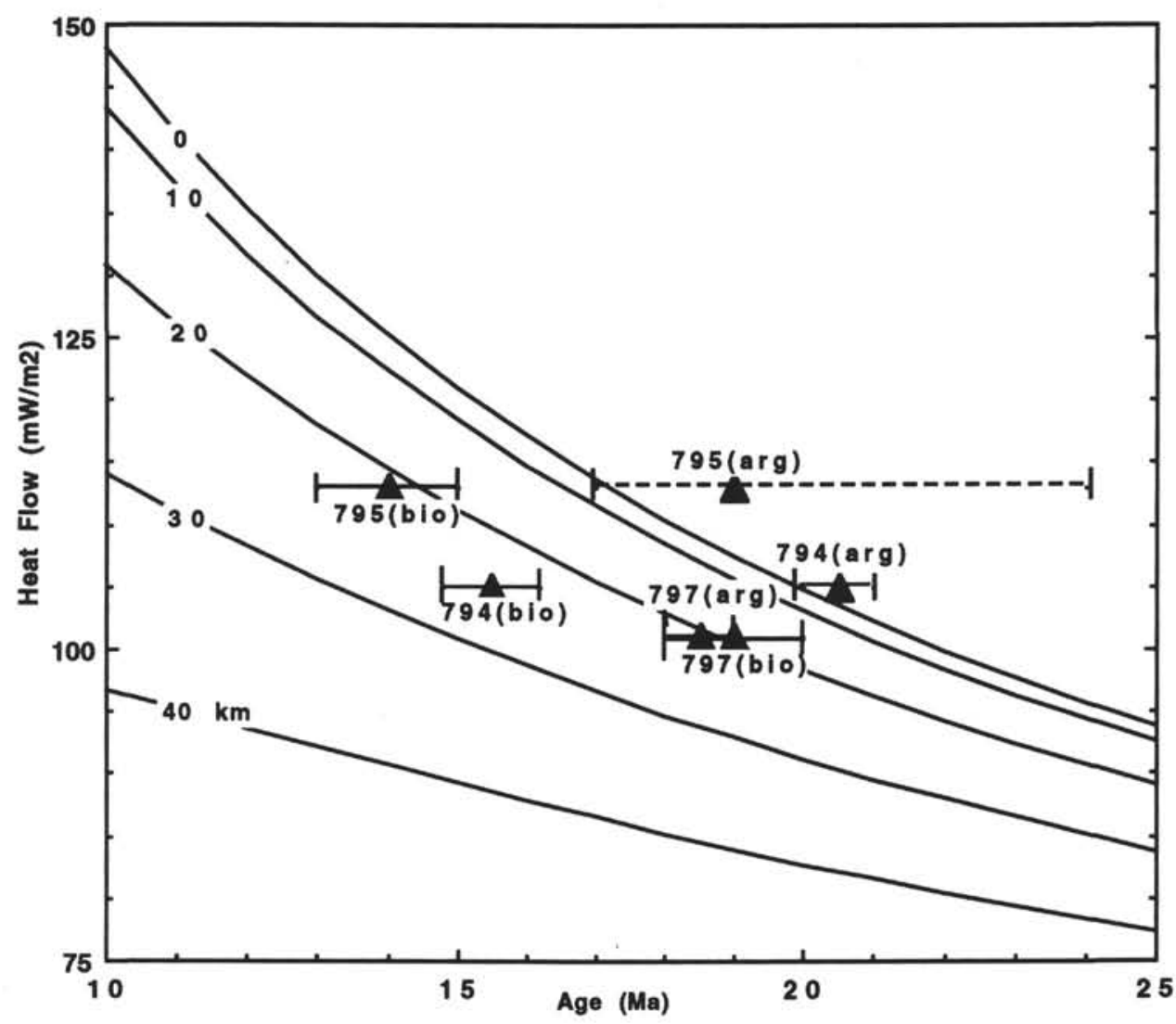

Figure 7. Surface heat flow vs. age curves for five thicknesses of lithosphere immediately after stretching. The heat flow at three sites where drilling reached acoustic basement are shown. Each heat flow value is plotted vs. age estimates from biostratigraphic data (bio) and ${ }^{40} \mathrm{Ar} /{ }^{39} \mathrm{Ar}$ ages of igneous rocks (arg).

conclusions, which cannot be easily resolved with the existing data. The age estimate based on sedimentation rates (14 Ma) is compatible with the heat flow value at Site 795, if we assume a thickness for $D$ of about $20 \mathrm{~km}$. The average ${ }^{40} \mathrm{Ar} /{ }^{39} \mathrm{Ar}$ age (about $19 \mathrm{Ma}$ ) is compatible with an oceanic model, if the parameter group $\sqrt{K \rho c} \cdot T_{m}$ has a higher value than PPOM (Fig. 7); however, experimental data by Yamashita and Fujii (this volume) indicate that the melting temperature of magmas in the Yamato Basin is about $1330^{\circ} \mathrm{C}$, which is virtually the same as that used in PPOM, and there is no evidence that $\sqrt{K \rho c}$ in the Japan Sea lithosphere is significantly different from that in the Pacific Ocean.

Better knowledge of the age of the lithosphere at Site 795 and the value of $T_{\mathrm{m}}$ are important because they have implications for the timing of the opening of the western Japan Basin. As Figure 1 shows, Site 795 lies within a region of elevated heat flow, whereas the average heat flow in the western Japan Basin is significantly lower ( $q=85$ to $90 \mathrm{~mW} / \mathrm{m}^{2}$ ). If the age of basement at Site 795 is $14 \mathrm{Ma}$, as the biostratigraphic data indicate, and if $T_{\mathrm{m}}=1330^{\circ} \mathrm{C}$, then the age of the western part of the basin, estimated from heat flow, is about $25 \mathrm{Ma}$. A significant difference in age between the eastern and the western parts of the Japan Basin suggests that it may have opened in two stages that were separated by a tectonically quiet period.

\section{Thermal History of Japan Sea Sediments and Silica Diagenesis}

Temperature profiles and thermal conductivities measured at all Leg 127 and 128 sites permitted temperatures at the opal-A/opal-CT boundary, the opal-CT/quartz transition, and the sediment/igneous rock interface to be estimated accurately (Fig. 6) . The temperature at the opal-A/opal-CT boundary is of particular interest because the location of this diagenetic front in the sedimentary section is primarily controlled by the integrated temperature history of the layer in which the transition is presently found (Mizutani, 1966; Tada et al., 1990).

The Japan Sea provides a relatively uncomplicated natural laboratory in which to study silica diagenesis. In the areas drilled during Legs 127 and 128, the accumulation of highly silicious sediments has been nearly continuous. The cores and downhole measurements conducted in the Japan Sea provide comprehensive data about the present-day and past environments and allowed us to test models of the thermochemical kinetics of silica diagenesis. The transition from amorphous biogenic silica (opal-A) to precipitated cristobalite (opalCT) is clearly seen at all of the sites, but at different depths below the seafloor in sediments of different ages and at different temperatures (Table 4). In general, an inverse relationship exists between temperature and age of the sediment, where the current transition is located.

At all sites, the opal-A/opal-CT transition is marked by a $20 \%$ to $25 \%$ decrease in porosity, and consequently, it is readily detected in profiles of physical properties vs. depth, based on measurements in core samples (Nobes et al., this volume). The transition produces a prominent reflector that is widely seen in seismic sections in the Japan Sea (Tamaki, 1988). At all but one of the drill sites, this transition is remarkably abrupt, commonly confined to one $1.5-\mathrm{m}$ core section. The transition is gradual only at Site 796 , where it occurs within a zone 25 to $30 \mathrm{~m}$ thick.

The transition zone advances upward in the sedimentary section with time as increasing depth of burial leads to higher temperatures. The present-day location and temperature of the opal-A/opal-CT transition in the sedimentary section depends on its thermal history, which is well constrained by heat flow measurements, basement age 
Table 4. Temperature and age of opal-A/opal-CT transition at Leg 127/128 sites.

\begin{tabular}{lcclc}
\hline Site & $\begin{array}{c}\text { Depth } \\
(\mathrm{mbs})\end{array}$ & $\begin{array}{c}\text { Temperature } \\
\left({ }^{\circ} \mathrm{C}\right)\end{array}$ & $\begin{array}{c}\text { Age } \\
(\mathrm{Ma})\end{array}$ & $\begin{array}{c}\text { Heat flow } \\
\left(\mathrm{mW} / \mathrm{m}^{2}\right)\end{array}$ \\
\hline 794 & 293 & 36.5 & 7.9 & 105 \\
795 & 325 & 44.0 & 5.2 & 113 \\
796 & $215-250$ & $40-45$ & $6-6.5$ & 156 \\
797 & 299 & 36 & 8.0 & 101 \\
798 & 455 & 51 & 3.75 & 101 \\
799 & 450 & 46 & 6.4 & 92 \\
\hline
\end{tabular}

"The shipboard analysis of sedimentation rates estimated an age of about 6.1 Ma for the opal-A/opal-CT transition at 797 (Tamaki, Pisciotto, Allan, et al., 1990). This age was based on finding $T$. schraderi in two carbonate nodules recovered from Core 127-797B-37X. This datum required a relatively fast sedimentation rate across the opal-A/opal-CT boundary and an anomalously slow rate between this datum and the next marker. It appears likely that the nodules came from higher in the hole for if this datum is ignored the sedimentation rate remains relatively uniform, and the age of the opal-A/opal-CT boundary is about $8.0 \mathrm{Ma}$, which we have assumed as the more correct age.

determinations, and the paleostratigraphy defined by the Japan Sea drilling results.

Opal-A in Japan Sea sediments consists almost entirely of diatom tests. According to earlier studies (Kastner et al., 1977), the conversion to opal-CT requires dissolution of the diatom tests into the pore waters as $\mathrm{Si}(\mathrm{OH})_{4}$, and reprecipitation of the silica as dispersed crystalline cristobalite in the sediment matrix. The rate of precipitation of opal-CT at the opal-A/opal-CT boundary is the reaction of interest and that reaction is controlled by the concentration of dissolved silica and the Arrhenius rate constant, $k_{1}$. The rate of depletion of the dissolved silica can be expressed as

$$
\frac{d[C]}{d t}=-k_{1}[C]
$$

where $[C]$ is the concentration of dissolved silica, and

$$
k_{1}=A \cdot \exp \left[\frac{-E_{a}}{R T}\right] \text {. }
$$

In Equation 7, $\mathrm{A}$ is the pre-exponential constant, $E_{\mathrm{a}}$ is the activation energy of the precipitation reaction, $R$ is the ideal gas constant, and $T$ is the temperature in degrees kelvin. For our study of the evolution of the opal-A/opal-CT front, $k_{1}$ is a function of time since the temperature within a given layer increases with time. Integration of Equation 6 over time $t$ gives

$$
\ln \left(\frac{[C]}{\left[C_{0}\right]}\right)=-k_{1} \int_{t_{d}}^{t_{p}} \exp \left[\frac{-E_{a}}{R T(t)}\right] \cdot d t,
$$

where $\left[C_{0}\right]$ is the concentration of silica in the pore water, and $T(t)$ is the temperature history of the layer where the opal-A/opal-CT transition is presently found. The time $t$ is measured from the time of formation of the basin, $t_{\mathrm{d}}$ is the time that the layer containing the opal-A/opal-CT boundary was deposited on the seafloor, and $t_{\mathrm{p}}$ is the present age of the basin. The progress of the reaction thus will be controlled by the right side of Equation 8 . The values of $A$ and $E_{\mathrm{a}}$ for opal-A to opal-CT reaction have been determined experimentally by Mizutani (1966). Below, we will show that the present location and temperature of the opal-A/opal-CT transition constrains to some degree the value of the activation energy.

The thermal history of a sedimentary layer deposited in a basin in which sediment is accumulating at a uniform rate can be approximated by combining the expression for surface heat flow from the lithosphere as a function of time, based on a thermal model of basin formation with the sedimentation rate. For example, seafloor heat flow predicted by the simple model of basin formation described in Appendix B is

$$
q(0, t)=\frac{K_{B} T_{M}}{D} \cdot \operatorname{erf}\left[\frac{D}{2 \sqrt{\kappa t}}\right] .
$$

For a uniform sedimentation rate, $\mathrm{S}$, the temperature of a layer deposited at time $t_{\mathrm{d}}$ is approximated by:

$$
T(t)=T_{w}+S \cdot\left(t-t_{d}\right) \cdot \frac{q(0, t)}{K_{s}}, \text { for }\left(t>t_{d}\right)
$$

$\mathrm{K}_{\mathrm{s}}$ is the thermal conductivity of the sediment. For this study, we assumed that the basin age was that estimated from the ${ }^{40} \mathrm{Ar} /{ }^{39} \mathrm{Ar}$ method; however, test calculations show that if the biostratigraphic estimates of the age are used, it would not make a significant difference in the results.

We calculated the progress of the $\mathrm{Si}(\mathrm{OH})_{4}$ to opal-CT reaction in the layer where the boundary is now found in Hole 794A using Equation 8 . The definition and values of parameters used in the model are given in Table 5. This value of the progress was then used as a reference, and we computed the time required for a layer deposited at time $t_{\mathrm{d}}$ to reach the same level of progress for a wide range of sedimentation rates. Once the time was determined, the temperature was calculated using Equation 10.

In Figure 8, curves representing equal progress of the $\mathrm{Si}\left(\mathrm{OH}_{4}\right)$ to opal-CT reaction for activation energies of 14,17 and $20 \mathrm{kcal} / \mathrm{mole}$ that pass through the temperature and age point of Site 974 have been plotted in a diagram similar to that of Mizutani (1966). The temperatures and ages of the opal-A/opal-CT boundary at all six sites have been plotted in the same figure and show reasonable agreement with the model using an activation energy of $17 \mathrm{kcal} / \mathrm{mole}$, which is the value determined experimentally by Mitzutani (1966) at $10 \mathrm{MPa}$. An important result of the model is that the temperature at the opalA/opal-CT boundary can vary from $25^{\circ}$ to more than $50^{\circ} \mathrm{C}$ in a Neogene basin, depending on the rate of sedimentation, which demonstrates that time as well as temperature determine the current location of the opal-A/opal-CT transition in the sedimentary section.

Because the opal-A/opal-CT transition forms such a distinct reflector on many seismic lines in the Japan Sea, there has been a strong interest in using the depth to this reflector as an estimator of the geothermal gradient, in a manner similar to the way that gas hydrate layers are used for this purpose (e.g., Hein et al., 1978; Kuramoto et al., this volume). It is clear from the preceding analysis that the depth to the opal-A/opal-CT transition would provide a reasonable estimate of geothermal gradient, if the sedimentation rate were known independently, or if the seismic stratigraphy could be tied to that in a nearby drill hole that intersects the transition zone. The method has the greatest potential for estimating the lateral trend of heat flow in the vicinity of a location where the relation between temperature gradient and depth of the opal-A/opal-CT horizon has been established directly.

Table 5. Model parameters for lithosphere evolution and the progress of the opal-A/opal-CT reaction at Site 794.

\begin{tabular}{lcc}
\hline Parameter & Symbol & Value \\
\hline Current age of the basin & $t_{\mathrm{p}}$ & $20 \mathrm{Ma}$ \\
Age of the opal-A/opal-CT boundary & $t_{\mathrm{p}}^{-t_{\mathrm{d}}}$ & $7.9 \mathrm{Ma}$ \\
Sedimentation rate & $S$ & $36.9 \mathrm{~m} / \mathrm{m} . \mathrm{y} \cdot$ \\
Initial thickness of lithosphere & $D$ & $20.0 \mathrm{~km}$ \\
Initial temperature of asthenosphere & $T_{\mathrm{m}}$ & $1333^{\circ} \mathrm{C}$ \\
Conductivity of lithosphere & $K_{\mathrm{B}}$ & $3.0 \mathrm{~W} / \mathrm{m} \cdot \mathrm{K}$ \\
Conductivity of sediment above opal-A/opal-CT & $K_{\mathrm{s}}$ & $0.85 \mathrm{~W} / \mathrm{m} \cdot \mathrm{K}$ \\
Thermal diffusivity of lithosphere & $K$ & $2.0 \times 10^{-7}$ \\
Volumetric heat capacity & $\rho_{c}$ & $1.5 \times 10^{7}$ \\
Activation energy & $E_{\mathrm{a}}$ & $17 \mathrm{Kcal} / \mathrm{mole}(71 \mathrm{~kJ} / \mathrm{mole})$ \\
Ideal gas constant & $R$ & $8.31 \mathrm{~W} / \mathrm{mole} \cdot \mathrm{K}$ \\
Pre-exponential constant & $A$ & $7.19 \times 10^{5}$ \\
\hline
\end{tabular}




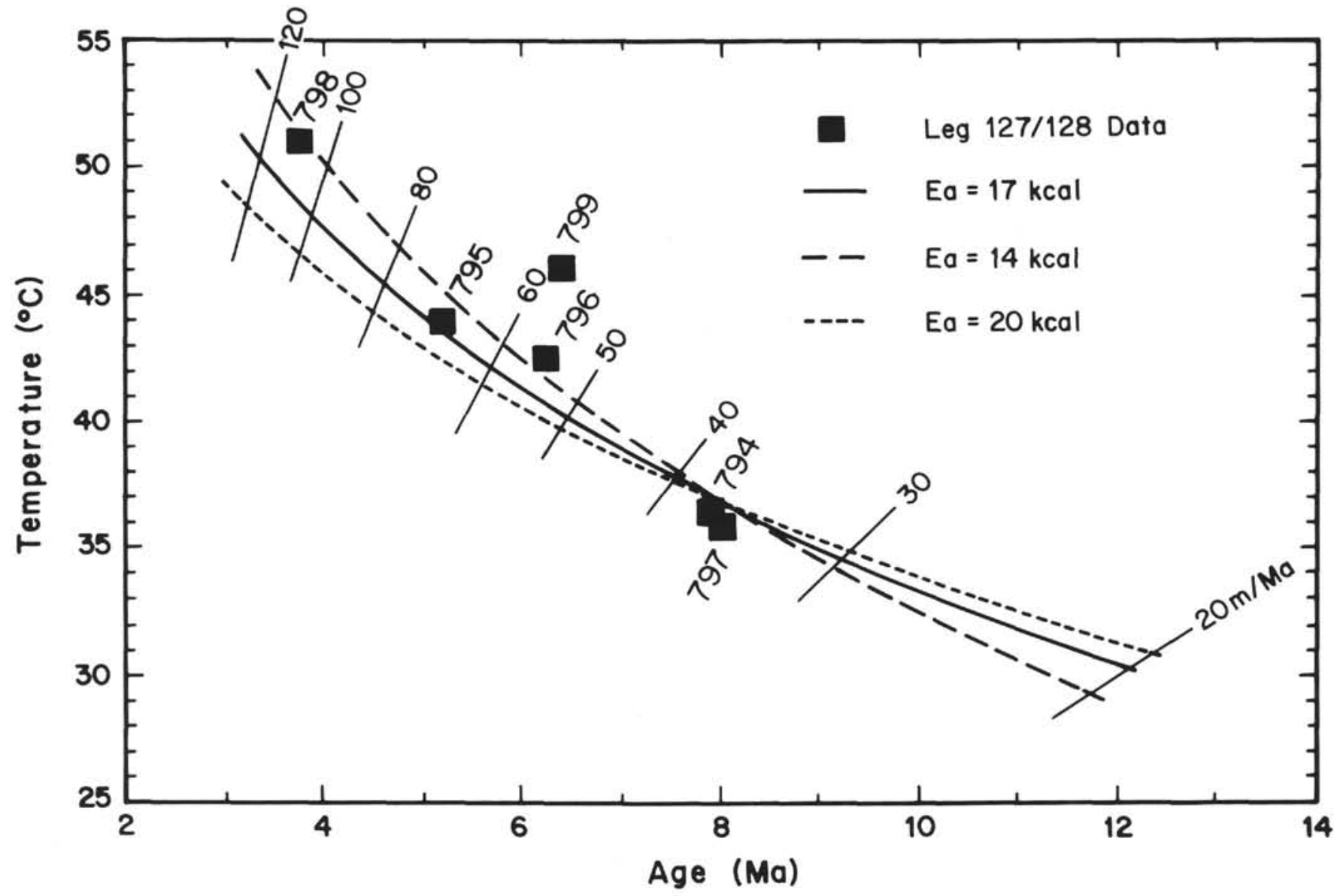

Figure 8. Temperature vs. age for the opal-A/opal-CT transition zones at Legs 127 and 128 drilling sites. These are compared with curves corresponding to the same progress of the $\mathrm{Si}(\mathrm{OH} 4)$ /opal-CT reaction calculated for Site 794. Intersecting lines are lines of equal sedimentation rate in meters per million years.

\section{CONCLUSIONS}

1. Downhole temperature and thermal conductivity measurements in core samples recovered during Legs 127 and 128 resulted in five accurate measurements of the heat flow through the seafloor and accurate estimates of temperature vs. depth over the drilled sections. The heat flow values measured at these sites are in excellent agreement with the nearby seafloor measurements and provide an important validation that these measurements accurately represent the level and distribution of heat flow from the Japan Sea basins.

2. A heat flow value at Site 796 was determined on the crest of the Okushiri Ridge that yielded an anomalously high heat flow of $156 \mathrm{~mW} / \mathrm{m}^{2}$. This is one of the highest heat flow observations in the Japan Sea.

3. Drilling during Legs 127 and 128 sampled basaltic rocks that form the acoustic basement in the Yamato and Japan basins. Estimates of the age of acoustic basement rocks have been made by isotopic dating of the basalts and by extrapolation of sedimentation rates to acoustic basement; however, preliminary results of these two methods are not in agreement. Here, we have compared the preliminary age estimates and heat flow with values predicted by a thermal model of a lithosphere that forms by stretching. These data and comparisons do not provide a clear resolution of questions of timing of opening of the Japan and Yamato basins, but do define the unresolved issues more clearly.

Extrapolation of sedimentation rates at Site 795 to the sediment/igneous contact yielded an age of $14.0 \pm 1.0 \mathrm{Ma}$. This age estimate for basement and the observed heat flow $\left(113 \mathrm{~mW} / \mathrm{m}^{2}\right)$ could be brought into accord only if the lithosphere had a thickness of about $20 \mathrm{~km}$ immediately after opening of the basin. By contrast, the average estimated basement age based on isotopic dating is about $19 \mathrm{Ma}$. This age and the observed heat flow would be in accord with predictions of an oceanic plate model $(D=0)$ only if the parameter group $\sqrt{K \rho c} \cdot T_{M}$ has a higher value (see Fig. 7 and Table 5). However, a higher asthenospheric temperature is not in accord with experimental results of Yamashita and Fugii (this volume). The significant difference in heat flow between the eastern and western parts of the Japan Basin, $110 \mathrm{~mW} / \mathrm{m}^{2}$ vs. $85 \mathrm{~mW} / \mathrm{m}^{2}$, suggests an appreciable age difference.

The Yamato Basin data are in reasonable accord with a stretching model of basin formation if $D$ equals 20 to $30 \mathrm{~km}$. The slightly higher heat flow at Site 794, compared with that of Site 797, suggests that the lithosphere is about 1 Ma younger below this site. If this inference is correct, it suggests problems with the estimate of basement age based on biostratigraphic evidence, which indicated a relatively large difference in age (about $5 \mathrm{Ma}$ ), and with the estimate based on ${ }^{40} \mathrm{Ar} /{ }^{39} \mathrm{Ar}$ dates, which indicated a younger age for basement at Site 797.

4. The accurate estimates of temperatures in the sedimentary section, the biostratigraphy, and estimated age of basin formation provided an opportunity to test thermochemical models of silica diagenesis. The present location of the opal-A/opal-CT transition in the sedimentary section is controlled by the thermal history of the layer in which the transition is found today. Comparison of the ages and temperatures of the layer in which this transition is now found at all sites is compatible with an activation energy of 14 to $17 \mathrm{kcal} / \mathrm{mole}$. 


\section{ACKNOWLEDGMENTS}

We are indebted to Barry Weber and Mike Reitmeyer for their expert operation of the WSTP tool during Leg 127. John Griffin kindly provided us with results of downhole measurements, and Kiyoshi Suyehiro provided us with conductivity measurements from Leg 128 and they kindly allowed us to use their results in this study. David Nobes, Shin-ichi Kuramoto, and Marcus Langseth were physical properties specialists during Leg 127 and shared the task of making the hundreds of thermal conductivity and index property measurements that were essential for this study. Discussions with Philip Froelich and Miriam Kastner concerning silica diagenesis were extremely helpful. This work was supported by a grant from the U.S Science Support program of the National Science Foundation's Ocean Drilling Program Office.

\section{REFERENCES}

Carslaw, H.S., and Jaeger, J.C., 1959. Conduction of Heat in Solids (2nd ed.): Oxford (Clarendon Press).

Hein, J.R., Scholl, D.W., Barron, J.A., Jones, M.G., and Miller, J., 1978. Diagenesis of late Cenozoic diatomaceous deposits and formation of the bottom simulating reflector in the southern Bering Sea. Sedimentology. 25:155-181.

Hyndman, R.D., Langseth, M.G., and Von Herzen, R.P., 1987. Deep Sea Drilling Project geothermal measurements: a review. Rev. Geophys., 25:1563-1582.

Ingle, J.C., Jr., 1975. Summary of late Paleogene-Neogene stratigraphy, paleobathymetry, and correlations, Philippine Sea and Sea of Japan regions. In Karig, D.E., Ingle, J.C., Jr., et al., Init. Repts. DSDP, 31: Washington (U.S. Govt. Printing Office), 837-855.

Karig, D.E., 1971. Origin and development of marginal basins in the western Pacific. J. Geophys. Res., 84:6796-6802.

Kastner, M., and Gieskes, J.M., 1983. Opal-A to Opal-CT transformation: a kinetic study. In Iijima, A., Hein, J.R., and Siever, R. (Eds.), Siliceous Deposits in the Pacific Region: Amsterdam (Elsevier), 211-228.

Kastner, M., Keene, J.B., and Gieskes, J.M., 1977. Diagenesis of siliceous oozes - I. Chemical controls on the rate of opal-A to opal-CT transformation, an experimental study. Geochim. Cosmochim. Acta, 41:1041-1059.

Kawai, N., Nakajima, T., and Hirooka, K., 1971. The evolution of the island arc of Japan and the formation of granites in the Circum-Pacific Belt. J. Geomagn. Geoelectr., 23:267-293.

Ludwig, W.J., Murauchi, S., and Houtz, R.E., 1975. Sediments and structure of the Japan Sea. Geol. Soc. Am. Bull., 86:651-664.

McKenzie, D., 1978. Some remarks on the development of sedimentary basins. Earth Planet. Sci. Lett., 40:25-32.

Mizutani, S., 1966. Transformation of silica under hydrothermal conditions. J. Earth Sci., Nagoya Univ., 14:56-88.

Otofuji, Y., and Matsuda, T., 1983. Paleomagnetic evidence for clockwise rotation of southwest Japan. Earth Planet. Sci. Lett., 62:349-359.

1985. Paleomagnetic evidence for Miocene counterclockwise rotation of northeast Japan-rifting process of the Japan Arc. Earth Planet. Sci. Lett., 75:265-277.

Parsons, B., and Sclater, J.G., 1977. An analysis of the variation of ocean floor bathymetry and heat flow with age. J. Geophys. Res., 82:803-827.

Pollack, H.N., and Chapman, D.S., 1977. On the regional variation of heat flow, geotherms and lithospheric thickness. Tectonophysics, 38:279-296.

Ratcliffe, E.H., 1960. The thermal conductivities of ocean sediments. J. Geophys. Res., 65:1535-1541.

Royden, L., Sclater, J.G., and Von Herzen, R.P., 1980. Continental margin subsidence and heat flow: important parameters in formation of petroleum hydrocarbons. AAPG Bull., 64:173-187.

Tada, R., 1990. Compaction and cementation in siliceous rocks and their possible effect on bedding enhancement. In Einsele, G., Ricken, W., and Seilacher, A. (Eds.), Cycles and Events in Stratigraphy: New York (Springer-Verlag).

Tamaki, K., 1986. Age estimation of the Japan Sea on the basis of stratigraphy, basement depth, and heat flow data. J. Geomagn. Geoelectr, $38: 427-446$

- 1988. Geological structure of the Japan Sea and its tectonic implications. Chishitsu Chosasho Geppo, 39:269-362.
Tamaki, K., Pisciotto, K., Allan, J., et al.,Proc. ODP, Init. Repts., 127: College Station, TX (Ocean Drilling Program).

Von Herzen, R.P., and Maxwell, A.E., 1959. The measurement of thermal conductivity of deep-sea sediments by a needle-probe method. J. Geophys. Res., 64:1557-1563.

Watanabe, T., Langseth, M.G., and Anderson, R.N., 1977. Heat flow in back-arc basins of the Western Pacific. In Talwani, M., and Pitman, W., III (Eds.), Island Arcs, Deep Sea Trenches and Back-Arc Basins. Am. Geophys. Union, Maurice Ewing Ser., 1:137-161.

Yamano, M., Uyeda, S., Uyeshima, M., Kinoshita, M., Nagihara, S., Boh, R., Jujisawa, H., 1987. Report on DELP 1985 Cruises in the Japan Sea. Part V: Heat flow measurements. Tokyo Daigaku Jishin Kenkyusho Iho, $62: 417-432$

Yasui, M., Kishii, T., Watanabe, T., and Uyeda, S., 1968. Heat flow in the Sea of Japan. In Knopoff, L. (Ed.), The Crust and Upper Mantle of the Pacific Area. Am. Geophys. Union Monogr. Ser., 12:3-16.

Yasui, M., and Watanabe, T., 1965. Studies of the thermal state of the earth. The 16th paper terrestrial heat flow in the Japan Sea. Tokyo Daigaku Jishin Kenkyusho Iho, 43:549-563.

Yokota, T., Kinoshita, H., and Uyeda, S., 1979. New DSDP (Deep Sea Drilling Project) downhole temperature probe utilizing IC RAM (Memory) elements. Tokyo Daigaku Jishin Kenkyusho Iho, 54:441-462.

\section{Date of initial receipt: 25 March 1991 \\ Date of acceptance: 17 January 1992 Ms 127/128B-227}

\section{APPENDIX A}

Comments on the Reliability of Bottom-Hole Temperature Measurements Using the WSTP

A number of operational circumstances can lead to invalid formation temperature measurements using the WSTP. A good guide to the reliability of recorded temperatures is the temperature history after penetration, as discussed by Hyndman et al. (1987). A record that shows a smooth and steady equilibration toward the in-situ formation temperature usually indicates a valid measurement.

Another important test is an in-situ check on probe calibration made by holding the probe for a few minutes at the seafloor, where the temperature is usually known from hydrographic measurements. The test can be repeated after penetration to test for a change of calibration. This second test can be misleading because warm water is drawn up the pipe by the core barrel as it is hoisted, which causes the temperature recorded inside the pipe at the seafloor to be a degree or so higher than that of the bottom water. Figure 2 shows an example of this effect. A valid calibration check after penetration can be made by vigorously circulating seawater down the pipe for few minutes while the probe is held at the at level of the seafloor. A calibration after penetration is recommended when damage to the probe during penetration is suspected.

The typical temperature record in Figure 2 can be extrapolated to yield a valid formation temperature. However, during Leg 127 some runs with the WSTP yielded unreliable sediment temperature measurements, even though the temperature record in the sediment appears normal. The only evidence that the measurements are not valid is that they fall well below the temperature vs. depth trend of the other temperature measurements. These false measurements probably result from flooding of permeable sediments ahead of the drill bit with cold circulating sea water. At Hole 796A, we noted that cores taken subsequent to the anomalous temperature runs contained a significant amount of silt and sand, which would give the sediments relatively high permeabilities and would permit invasion of cold circulating water. Anomalously low temperature values were also observed below $295 \mathrm{~m}$ in Hole 794A; these were probably the result of the fracturing of semiconsolidated sediments ahead of the bit and the subsequent flooding of the fractured zone. The record of equilibration in the sediment appears normal because a sufficently large volume of material ahead of the bit was cooled so that the probe responded as though it had been immersed in an infinite medium during the 20-min observation period.

Two precautions are recommmended to avoid false readings of this type:

1. Take many measurements in low permeability sediments to use as a reference trend. 
2. Examine the contents of cores taken subsequent to the probe measurements for evidence of higher permeability material, such as the recovery of coarse-grained sediment of small-scale fracturing of the core sample.

\section{APPENDIX B}

An Analytical Solution for a One-Dimensional Model of the Thermal Evolution of a Basin Formed by Thinning of the Lithosphere

Assumptions of the model are that an original lithosphere with a thickness $D^{\prime}$ stretches instantaneously so that it thins to a thickness D. As a consequence, the thermal gradient in the lithosphere after stretching will be approximately $D^{\prime} / \mathrm{D}$ times larger than the initial gradient. If we assume that heat is lost by vertical conduction subsequent to stretching, the evolution of surface heat flow and vertical temperature distribution can be written as an analytical expression. The definition of parameters and symbols used are given in Table 5 .

Assume that the initial temperature distribution $T(z, 0)$ is given by,

$$
T(z, 0)=\frac{T_{m}}{D} \cdot z, \text { for } 0<z<D,
$$

and,

$$
T(z, 0)=T_{m}, \text { for } z \geq D,
$$

where $\mathrm{z}$ is the depth below the seafloor and $T_{\mathrm{m}}$ is the temperature of the asthenosphere.

A general solution to the diffusion equation,

$$
\frac{\partial T}{\partial T}=\kappa \cdot \frac{\partial^{2} T}{\partial z^{2}},
$$

with the boundary condition $T(0, t)=0$ is given by Carslaw and Jaeger (1959, p. 59):

$$
\begin{gathered}
T(z, t)=\frac{1}{2 \sqrt{\pi \kappa t}} \int_{0}^{\infty} T\left(z^{\prime}, 0\right) \\
\left\{e^{-\left(z-z^{\prime}\right)^{2} / 4 \mathrm{\sigma} \sigma}-e^{-\left(z+z^{\prime}\right)^{2} / 4 \times t}\right\} d z^{\prime} .
\end{gathered}
$$

The evaluation of this integral with the initial conditions defined in Equations $\mathrm{A} 1 \mathrm{~A}$ and $\mathrm{A} 1 \mathrm{~B}$ yields:

$$
\begin{aligned}
T(z, t) & =\frac{T_{m}}{2}\left[(z-D) \operatorname{erf}\left(X_{1}\right)+(z+D) \operatorname{erf}\left(X_{2}\right)\right] \\
& +\frac{T_{m}}{2} \sqrt{\frac{\kappa}{\pi}}\left[e^{-\left(X_{1}\right)^{2}}-e^{-\left(X_{1}\right)^{2}}\right]
\end{aligned}
$$

where

$$
\begin{aligned}
& X_{1}=(D-z) / 2 \sqrt{\kappa t}, \\
& X_{2}=(D+z) / 2 \sqrt{\kappa t},
\end{aligned}
$$

and

$$
\operatorname{erf}(X)=\frac{2}{\sqrt{\pi}} \int_{0}^{X} e^{-\beta^{2}} d \beta,
$$

(from Carslaw and Jaeger, 1959, Appendix II).

The surface heat flow is given by

$$
q(0, t)=\frac{K_{B} \cdot T_{m}}{D} \operatorname{erf}[D / 2 \sqrt{\kappa \tau}]
$$

When $D=0$,

$$
q(0, t)=\frac{K_{B} \cdot T_{m}}{\sqrt{\pi \kappa \tau}}
$$

which is the solution for a half-space cooling conductively from an initial temperature of $T_{\mathrm{m}}$. 